\title{
Meningkatkan Hasil Belajar Menari Kreatif melalui Pendekatan Pembelajaran Piaget Dan Vygotsky
}

Melina Surya Dewi

Institut Kesenian Jakarta

\begin{abstract}
This paper discusses the result of a research of learning improvement which uses the action research method with one cycle. The research aims at: 1) improving the creative dance learning; and 2) understanding the effectiveness of the Piaget and Vygotsky learning approaches. The sample of the research is B-class students of Santa Ursula Kindergarten of Central Jakarta. Based on the data obtained quantitatively (pre-test and post-test) and class observation, it could be concluded that there is an improvement to the outcomes of the students dance learning, and that the Piaget and Vygotsky learning approaches are effective to be implemented at B-class of Santa Ursula Kindergarten. Based on the research outcomes, it can be recommended that Kindergarten teachers use the Piaget and Vygotsky learning approaches which are adapted to the condition and situation of each school.
\end{abstract}

Key words: creative dance learning, Piaget and Vygotsky learning approaches

\section{ABSTRAK}

Tulisan ini membahas hasil penelitian peningkatan pembelajaran yang menggunakan metode penelitian tindakan dengan satu siklus. Penelitian ini bertujuan untuk: 1) meningkatkan pembelajaran tari kreatif, dan 2) memahami keefektifan pendekatan pembelajaran Piaget dan Vygotsky. Sampel dari penelitian ini adalah siswa-siswa kelas B Taman Kanak-Kanak Santa Ursula Jakarta Pusat. Berdasarkan data yang diperoleh secara kuantitatif (pre-test dan post-test) dan observasi kelas, dapat disimpulkan bahwa ada peningkatan terhadap hasil pembelajaran tari para siswa, dan bahwa pendekatan pembelajaran Piaget dan Vygotsky efektif diimplementasikan pada kelas B Taman Kanak-Kanak Santa Ursula. Berdasarkan hasil penelitian tersebut, guru-guru Taman Kanak-Kanak disarankan untuk menggunakan pendekatan pembelajaran Piaget dan Vygotsky yang disesuaikan dengan situasi dan kondisi masing-masing sekolah.

Kata Kunci: belajar menari kreatif, pendekatan pembelajaran Piaget dan Vygotsky

\section{PENDAHULUAN}

Pada dasarnya seni terkait dengan kreativitas. Oleh karena itu bidang seni, antara lain seni tari mempunyai ruang yang luas untuk menumbuhkan kreativi- tas anak. Kreativitas perlu ditumbuhkembangkan sejak anak usia dini karena masa usia dini adalah masa keemasan, merupakan masa yang tepat untuk menumbuhkembangkan potensi anak termasuk potensi kreatif melalui tari. Namun ber- 
dasarkan pengamatan di lapangan terhadap pembelajaran bidang seni terutama seni tari, pada umumnya pembelajaran masih dilakukan melalui metode yang terpusat pada guru sebagai model, sementara anak menirukan gerak yang dilakukan oleh guru. Dalam hal ini anak-anak belajar menirukan bentuk tarian yang sudah jadi (tari bentuk), artinya anak-anak tidak dilibatkan secara kreatif-konstruktif dalam proses penemuan dan penyusunan gerak tari.

Sebenarnya anak-anak TK kelas B dapat mulai dilibatkan dalam proses penciptaan tari dengan gerak sebagai materi dasarnya, sesuai dengan kemampuan perkembangannya. Dalam pembelajaran tari dengan metode kreatif guru dapat melibatkan anak-anak secara aktif dalam proses penemuan dan perangkaian gerak. Sementara metode kreatif diyakini mampu menumbuhkan dan meningkatkan kreativitas siswa melalui stimulasi pemunculan ide, penemuan gerak, serta merangkaikan gerak temuannya secara konstruktif menjadi serangkaian gerak yang bermakna sebagai hasil ciptaan 'tari' anak.

Oleh karena itu kreativitas tari tidak hanya mencakup aspek gerak semata tetapi juga mencakup aspek berpikir kreatif dan konstruktif. Jika sejak dini melalui pembelajaran tari anak diajarkan dan dilatih untuk mengembangkan kreativitasnya maka diharapkan dapat berdampak terhadap kemampuan yang lainnya.

Di TK kelas B Santa Ursula pada tahun ajaran 2011-2012 telah dilakukan pembelajaran tari kreatif namun masih terbatas pada tujuan agar anak berani mengungkapkan ekspresi gerak yang ditemukannya secara spontan berdasarkan tema pembelajaran di TK kelas B. Gerak spontan atau improvisasi gerak tersebut sebagian besar dilakukan dengan menggunakan stimulus musik yang disiapkan oleh guru. Sehingga dengan demikian pencapaian belajar tari kreatif di TK kelas B Santa Ursula belum optimal karena pada hakikatnya belajar menari kreatif adalah belajar mencipta. Siswa dengan didampingi guru dapat mulai belajar untuk menemukan dan menyusun gerak tari secara konstruktif sesuai dengan ide yang merujuk pada tema pembelajaran di TK, menjadi suatu rangkaian gerak yang bermakna. Berdasarkan alasan tersebut maka penelitian ini perlu dilakukan untuk meningkatkan hasil belajar menari kreatif siswa yang merujuk kepada teori belajar konstruktivisme Piaget dan Vygotsky.

\section{PEMBAHASAN}

\section{Teori Kreativitas}

Kreativitas adalah konsep yang majemuk, multidimensional, dan tidak mudah dirumuskan. Namun kebanyakan peneliti akan mendefinisikan secara luas kreativitas sebagai proses memproduksi sesuatu yang orisinal dan bernilai (Sternberg, 2008: 398). Individu kreatif sebagaimana dipaparkan oleh Gruber (dalam Gardner, 1993: 171) adalah individu yang sangat lekat mempunyai perhatian serta perasaan menyenangi yang tinggi pada pekerjaannya, mereka memperlihatkan kebutuhan untuk melakukan sesuatu yang baru dan mempunyai sensitivitas yang tinggi untuk mencapai tujuan. Dari kedua penjelasan pakar psikologi tersebut dapat disimpulkan, kreativitas selain terkait pada proses dan produk, juga terkait pada kepribadian dengan minat dan kesenangan yang tinggi untuk menekuni 
bidang tertentu, dalam proses eksplorasi untuk menemukan ide baru di bidangnya yang mendasari terciptanya suatu produk kreatif.

Merujuk pada paparan tersebut maka kreativitas tidak tumbuh dan berkembang begitu saja, tanpa adanya sebuah persemaian yang kondusif dan pembelajaran yangmengundang. Dengan demikian sejak usia dini anak-anak perlu mendapatkan stimulasi belajar yang menumbuhkan kesenangan, ketekunan, dan minat bereksplorasi kreatif. Stimulasi tersebut bertujuan agar pada masa dewasa kelak potensi kreatif anak tumbuh dan berkembang optimal, mampu memproduksi sesuatu yang orisinal dan bernilai bagi dirinya dan masyarakat luas. Oleh karena itu ide kreatif yang tumbuh dari berpikir kreatif dan merupakan dasar dihasilkannya suatu produk kreatif, sangat penting untuk ditumbuhkembangkan sejak dini antara lain melalui belajar tari kreatif.

\section{Teori Berpikir Kreatif}

Produk kreatif didasarkan pada ide yang tumbuhkembang dari pemikiran kreatif yang mengacu pada ranah kognitif. Beberapa ahli psikologi mengajukan definisinya mengenai kreativitas yang berkaitan dengan berpikir kreatif seperti dipaparkan berikut ini.

William (dalam Clark, 1988: 49) menyatakan definisinya tentang berpikir kreatif yaitu proses mental didasarkan pada kognisi, berpikir produktif berpikir divergen, berpikir asosiatif, perilaku evaluatif, dan keterampilan komunikatif.

Menurut Guilford (dalam Vernon, 1982:11) berpikir kreatif adalah berpikir divergen yang menekankan kepada kegiatan pencarian jawaban melalui kebebasan berpikir yang tersebar ke berbagai arah untuk menemukan berbagai alternatif jawaban terhadap suatu permasalahan. Berpikir divergen dibedakan dengan berpikir konvergen, berpikir konvergen adalah berpikir untuk memperoleh satu jawaban yang benar.

Selanjutnya Kaufman dan Sternberg (2010: 415) menjelaskan tentang konsepsi Guilford tersebut di atas, sebagai berikut: Gagasan berpikir divergen atau Divergent Thinking (DT) sebagai proses berpikir kreatif dijelaskan dalam Structural of Intellect (SOI) Guilford. SOI menjelaskan bahwa proses ide diproduksi melalui perbedaan berpikir yang bergerak ke berbagai arah. Sementara berpikir konvergen yaitu berpikir ke satu arah biasanya mengarah untuk sebuah konvensi. Baik pemikiran divergen maupun pemikiran konvergen berperan dalam kreativitas.

Definisi Guilford tersebut (dalam Clark, 1988: 49) menyatakan, kreativitas adalah kelancaran, keluwesan berpikir, dan orisinalitas berpikir, kepekaan terhadap masalah, redefinisi, dan elaborasi yang dapat diklasifikasikan dalam kemampuan berpikir divergen.

Menurut Utami Munandar (1987: 50) secara operasional kreativitas dirumuskan sebagai kemampuan yang mencerminkan kelancaran, keluwesan (fleksibilitas) dan orisinalitas dalam berpikir, serta kemampuan untuk mengelaborasi (mengembangkan, memperkaya suatu gagasan). Utami Munandar (1977: 28-29) menjelaskan yang dimaksud dengan kelancaran (fluency) adalah kemampuan untuk mengungkapkan ide-ide secara cepat atau mengalir. Keluwesan (flexibility) adalah kemampuan untuk memproduksi berbagai ragam ideide secara bebas. Orisinal (originality) yaitu kemampuan untuk memproduksi ide-ide yang unik atau tidak biasa dari populasi di mana individu itu menjadi anggotanya. 
Selanjutnya dalam taksonomi Bloom ranah kognitif (Santrock, 2008: 412-413) terdapat enam tingkatan pemikiran mulai yang rendah ke tingkat yang tinggi yaitu: (1) Pengetahuan (knowledge); (2) Pemahaman (comprehension); (3) Penerapan (application); (4) Analisis (analysis); (5) Sintesis (synthesis); dan (6) Penilaian (evaluation). Berpikir sintesis bercirikan berpikir ke berbagai arah atau berpikir divergen yang merupakan kemampuan untuk menciptakan produk, metode, pola baru dari unsur-unsur yang ada atau dengan kata lain menggabungkan atau menyusun bagian-bagian menjadi keseluruhan yang baru. Maka berpikir sintesis adalah berpikir kreatif atau berpikir divergen.

Dari ranah kognitif Bloom tersebut, dapat disimpulkan bahwa berpikir kreatif untuk menciptakan ide tari dapat ditumbuhkembangkan pada anak-anak antara lain melalui cara berpikir sintesis, yaitu dengan menggabungkan atau menyusun konsep-konsep gerak tari yang telah ditemukan atau menjadi sebuah rangkaian gerak tari yang bermakna.

Sehubungan dengan aplikasi dan upaya menumbuhkembangkan kreativitas tari di TK kelas B diperlukan situasi proses mengajar dan belajar yang kondusif, antara lain guru perlu memahami kadar potensi kreativitas yang muncul, tumbuh dan berkembang berbeda-beda dari masing-masing individu anak. Potensi kreatif perlu dikembangkan karena merupakan salah satu kebutuhan kehidupan anak dalam bereksplorasi menemukan dan membangun pengetahuannya secara konstruktif. Selain itu guru perlu memahami bahwa bermain adalah dunia anak-anak, melalui bermain anak belajar sesuatu. Dengan demikian aplikasi pembelajaran tari kreatif di TK kelas B perlu dilakukan melalui belajar sambil bermain, melalui bermain anak-anak berimajinasi dan belajar kreatif (Russ dalam Runco, 1996: 34-36). Pembinaan kreativitas di dalam proses mengajar dan belajar di TK kelas B sepatutnya menjadi aktualisasi dari potensi kreatif yang ada pada siswa dalam suasana bermain yang kondusif dan menyenangkan.

\section{Teori Tari Kreatif}

Merujuk pada tari untuk anak-anak, Rudolf Laban (1879-1958) adalah pencetus modern educational dance atau yang kemudian dikenal juga dengan tari pendidikan (educational dance), tari kreatif (creative dance), tari ekspresif (expressive dance), serta gerak dan tari kreatif (creative movement and dance) yaitu suatu model pembelajaran tari yang menekankan pada proses belajar menari anak (child-centred approach), aktivitas belajar menari anak-anak dengan metode kreatif yang menekankan pada kebebasan berekspresi dalam menemukan gerak pribadi sebagai materi dasar tari.

Pemikiran Laban tersebut didukung oleh Smith (1994: 4) yang menjelaskan bahwa kontribusi afektif dalam pengalaman belajar menari kreatif akan menyumbang kepada perkembangan kepribadian anak. Mengajar dan belajar menari menggunakan metode kreatif tidak menekankan kepada produk, namun kepada proses belajar siswa dalam menemukan dan menciptakan gerak tarinya. Laban (1976: 12) menekankan bahwa belajar menari kreatif hendaknya dapat menyumbang sesuatu yang positif kepada perkembangan kepribadian siswa melalui proses belajarnya.

Pada aplikasinya di dalam proses belajar menari kreatif di sekolah guru perlu memberikan stimulasi pada siswa untuk tumbuhnya kebebasan, rasa keingin- 
tahuan, ketekunan dan sikap menghargai akan penemuan ide atau gerak siswa lain yang berbeda di dalam proses belajar menari kreatif di kelas.

Selanjutnya menurut Laban (1976) anak-anak usia dini mempunyai dorongan alamiah dan senang untuk melakukan ekspresi gerakan 'seperti tarian'. Dengan demikian merupakan saat yang tepat untuk memperkenalkan dunia tari kreatif sejak dini pada anak-anak, serta memberikan kesempatan kepada mereka untuk memunculkan keberanian berekspresi secara spontan melalui geraknya. Kesimpulan dari teori Laban tentang tari kreatif yaitu bahwa gerak manusia merupakan materi dasar dari tari kreatif yang dapat diekspresikan oleh anak-anak. Gerak tersebut adalah gerak keseharian atau gerak universal yang dapat dilakukan oleh anak-anak seperti berjalan, berputar, melompat, dan lain-lain. Materi gerak tersebut harus diaplikasikan oleh guru di kelas dalam mengajar dan belajar tari dengan metode kreatif, untuk memunculkan ungkapan gerak pribadi siswa.

\section{Perbandingan Metode Imitatif dan Kreatif}

Dalam memahami metode belajar menari kreatif, berikut ini dipaparkan uraian Barbara Haselbach (1978: 42-43) yang membandingkan metode kreatif dan metode imitatif di dalam mengajar-belajar menari.

\begin{tabular}{|l|}
\hline \multicolumn{1}{|c|}{ Metode Imitatif } \\
\hline 1. Pelaksanaan gerak sudah dibakukan \\
2. Mementingkan prestasi dan produk atau \\
bentuk akhir \\
3. Perlu dijaga agar tidak terjadi peniruan \\
gerak yang tidak benar (tidak sesuai \\
dengan aturan atau pakem) \\
4. Disiplin kelas lebih mudah dikendalikan, \\
karena gerak seragam
\end{tabular}

5. Manajemen waktu dalam mengajarbelajar lebih mudah dikendalikan untuk mencapai tujuan

6. Pengaturan tugas berdasarkan kemampuan penguasaan teknik yang diharapkan (melalui latihan dan pengulangan)

7. Menekankan kepada kerja untuk mencapai target menguasai sebuah tarian jadi

\section{Metode Kreatif}

1. Pelaksanaan gerak berdasarkan eksplorasi dan penemuan gerak indivi du

2. Mementingkan proses pengalaman belajar kreatif

3. Perlu dicermati, jika terjadi kurang nya bentuk

4. Disiplin kelas lebih sulit dikendalikan karena adanya kebebasan ber ekspresi gerak individu dalam ruang

5. Manajemen waktu mengajar-belajar memerlukan pertimbangan yang matang untuk mencapai tujuan

6. Pengaturan tugas berdasarkan ekspresi dan temuan individu

7. Menekankan kepada kerja mandiri untuk mengkonstruksi gerak atau menemukan gerak tari 


\begin{tabular}{|l|l|}
\hline \multicolumn{1}{|c|}{ Metode Imitatif } & \multicolumn{1}{c|}{ Metode Kreatif } \\
\hline $\begin{array}{l}\text { 8. Mengembangkan kekuatan pengamatan } \\
\text { dan imitasi }\end{array}$ & 8. $\begin{array}{l}\text { Mengembangkan imajinasi dan } \\
\text { kreativitas }\end{array}$ \\
$\begin{array}{l}\text { 9. Pembelajaran berpusat pada guru } \\
\text { 10. Menekankan pada berpikir konvergen }\end{array}$ & 9. $\begin{array}{l}\text { Pembelajaran berpusat pada siswa } \\
\text { 10. Menekankan pada berpikir divergen }\end{array}$ \\
\hline
\end{tabular}

Diadaptasi dari Haselbach (1978)

Teori Belajar Konstruktivisme menurut Piaget

Teori konstrukstivisme yang dikembangkan oleh Piaget pada pertengahan abad ke-20 merupakan salah satu teori belajar kognitif. Piaget berpendapat bahwa pada dasarnya setiap individu sejak kecil memiliki kemampuan untuk mengkonstruksi pengetahuannya sendiri. Sebagaimana dipaparkan oleh Suparno (1997: 28) konstrukstivisme menyakini bahwa pengetahuan adalah hasil konstruksi anak. Anak-anak mengkonstruksi pengetahuan mereka melalui interaksi mereka dengan objek, fenomena, pengalaman, dan lingkungan.

Pengetahuan merupakan suatu proses yang berkembang terus menerus. Dalam proses itu keaktifan seseorang untuk mengetahui sesuatu amat berperan dalam perolehan dan perkembangan pengetahuannya. Mengkonstruksi pengetahuan menurut Piaget dilakukan melalui proses asimilasi dan akomodasi terhadap skema yang sudah ada. Skema adalah struktur kognisi yang terbentuk melalui proses pengalaman. Asimilasi adalah proses penyempurnaan skema yang telah terbentuk, dan akomodasi adalah proses perubahan skema (Sanjaya, 2007: 123-124). Selanjutnya Piaget (dalam Suparno, 1997: 121) menyatakan bahwa karena pengetahuan adalah konstruk yang dibangun oleh anak itu sendiri, maka pada prinsipnya setiap anak memiliki konsep sendiri terhadap suatu pengetahuan yang telah diperolehnya. Perbedaan konsep setiap anak inilah yang menjadi dasar pengembangan potensi anak untuk berpikir kreatif.

Pada tataran aplikasi di kelas TK B guru perlu menyadari pemberian kesempatan untuk munculnya ide dan gerak tari yang berbeda pada setiap individu anak. Selain itu sehubungan dengan pembelajaran tari kreatif di kelas, guru hendaknya menumbuhkan suasana belajar yang kondusif, dengan memberikan dorongan dan pujian saat belajar sambil bermain. Suasana yang kondusif dibangun agar siswa dapat belajar menemukan dan menyusun temuannya yang dikonstruksi oleh siswa sebagai pengetahuan baru yang bermakna. Dalam hal ini guru bertindak sebagai motivator dan fasilitator bagi siswa.

Sebagai motivator dan fasilitator guru mengantar siswa kepada pengalaman penemuan gerak (discovery), penjelajahan gerak (exploration) dalam merangkaikan dan menyusun gerak tari baik secara individual maupun kelompok. Selain itu siswa perlu dihadapkan pada pemecahan masalah (problem solving) di dalam proses pembelajarannya (Murray, 1975: 24-25). Merujuk pada paparan Murray tersebut maka dalam belajar tari kreatif, anakanak belajar melalui pengalaman nyata. Sebagaimana dijelaskan oleh Sanjaya (2007: 123-124) pengetahuan yang diper- 
oleh anak melalui proses pemberitahuan atau ceramah guru tidak akan menjadi pengetahuan yang bermakna. Pengetahuan tersebut pada umumnya hanya diingat sementara setelah itu dilupakan. Dengan demikian belajar melalui perolehan pengalaman pribadi menjadi penting, dalam belajar secara kreatif dan konstruktif.

\section{Teori Zone Proximal Development (ZPD) menurut Vygotsky}

Menurut Vygotsky (dalam Kozulien dkk., ed., 2003: 39-64) perkembangan suatu perilaku terjadi pada dua tingkatan yang membentuk batas-batas ZPD. Batas bawah merupakan performansi yang dimiliki anak, yaitu apa yang diketahui dan dapat dikerjakan sendiri oleh anak saat ini, yang kemudian disebut sebagai independent performance. Tingkat yang lebih tinggi adalah tingkatan maksimum yang dapat diraih oleh anak dengan bantuan, oleh karenanya disebut sebagai assisted performance. Di antara assisted performance dengan independent performance terdapat bermacam tingkatan. Assisted performance dilakukan sebagai hasil interaksi antara anak dan orang lain yang lebih kompeten dibandingkan si anak.

ZPD tidak statis tetapi berubah sejalan dengan pencapaian anak terhadap tingkatan berpikir dan pengetahuan yang lebih tinggi. Oleh karena itu, perkembangan melibatkan suatu urutan yang secara konsisten mengubah zona. Melalui setiap perubahan, anak menjadi semakin mampu belajar keterampilan dan konsep yang kompleks. Apa yang dapat dilakukan oleh anak pada hari kemarin dengan bantuan, mungkin akan menjadi tingkat performansi independen pada hari ini. Ketika anak dihadapkan pada tugas yang lebih sulit, maka tingkat assisted performance yang baru kemudian muncul. Proses demikian terus berlangsung.

Pemahaman konsep performansi dan kompetensi sangat penting untuk memahami ZPD. Performansi mengacu pada suatu kondisi dimana anak dapat melakukan tugas pada tingkatan yang lebih tinggi tetapi pemahamannya belum optimal. Anak tidak memiliki pemahaman yang baik tentang tugas yang dapat dikerjakannya sebelum orang lain yang lebih mampu (More Knowledgeable Others) mengajarinya. Jika anak telah diberitahu dan memahami serta dapat melakukan tugas yang ia hadapi dalam waktu yang berulang maka ia telah dianggap kompeten terhadap tugas tersebut (Galloway,2011).

Dalam aplikasinya belajar tari kreatif di kelas, selain dengan bimbingan guru sebagai fasilitator, guru dapat membagi siswa dalam kelompok belajar antara siswa yang belum kompeten, berbaur dengan siswa yang sudah kompeten. Interaksi dapat berbentuk bantuan dari teman yang lebih mampu. Atau interaksi dapat berbentuk bantuan langsung dari guru dalam memberikan petunjuk, misalnya saat siswa melakukan eksplorasi gerak, guru mengajukan pertanyaan tentang gerak apa yang dilakukan anak serta menyuruh anak untuk menyatakan kembali ide gerak apa yang baru saja dilakukan, dengan tujuan siswa memahami makna gerakan yang ditemukannya.

\section{Perkembangan Kognitif Siswa Taman Kanak-kanak}

Menurut Piaget (Santrock, 2010: 39-42), perkembangan kognitif siswa TK kelas B berada dalam tahap praoperasional. Tahap ini ditandai dengan digunakannya simbol dalam mengekspresikan suatu objek dan pemikiran intuitif anak. Ke- 
mampuan anak dalam berpikir tentang objek atau kejadian mulai berkembang. Pada tahap ini, anak mulai mengenal simbol berupa kata, angka, gerak tubuh atau gambar untuk mewakili objek atau kejadian yang ada di sekitarnya.

Selanjutnya Muller, dkk (2009: 233234) memaparkan bahwa representasi suatu benda yang tidak tampak dengan menggunakan simbol atau tanda oleh anak, dimulai saat anak berumur 2 (dua) tahun. Penggunaan simbol ditandai oleh lima gejala (Suparno, 2001: 50-59), yaitu: (1) imitasi tidak langsung; (2) bermain simbolis; (3) menggambar, merupakan penghubung antara permainan simbolis dengan gambaran mental; (4) membuat gambaran mental yaitu penggambaran secara pikiran tentang suatu objek atau pengalaman yang lampau, yang merupakan suatu persepsi; dan (5) menggunakan bahasa ucapan, berawal dari satu kata, dengan cepat anak akan mengembangkan kemampuan berbahasanya. Perkembangan bahasa sangat berpengaruh terhadap kelancaran perkembangan konseptual dan perkembangan kognitif anak.

Mengacu pada paparan perkembangan kognitif Piaget tersebut, siswa yang duduk di bangku TK kelas B telah mampu berpikir simbolis. Dengan demikian ekspresi gerak tari dapat dijadikan saluran antara permainan gerak simbolis dengan gambaran mental anak. Permainan simbolis bersifat imitatif, siswa meniru objek dan kejadian yang dialaminya, misalnya siswa mampu dan senang menirukan gerak binatang seperti kelinci dan kodok yang pandai meloncat. Selain itu melalui pembelajaran tari kreatif, siswa dengan bimbingan guru diharapkan mampu mengembangkan skema yang telah dimilikinya melalui proses asimilasi dan ako- modasi. Sebagaimana di paparkan oleh Semiawan (2009:64) proses asimilasi dan akomodasi adalah faktor fundamental dalam fungsi intelektual (kognitif) anak yang merupakan transformasi proses berpikir.

Berbeda dari Piaget, menurut Vygotsky perkembangan kognisi sangat terkait dengan masukan dari orang lain. Akan tetapi, sama seperti Piaget, Vygotsky meyakini bahwa perolehan pengetahuan anak melalui konstruksi pengalaman personal masing-masing anak. Menurut Vygotsky pengalaman personal dan sosial tidak mungkin dipisahkan karena anak-anak memperoleh kemampuan baru ketika berinteraksi dengan lingkungan sosial (Guerra Cristin, Lev Semyonovich Vygotsky). (http://www.muskingum.edu/ psych/ psycweb/history/vygotsky.htm) got

Dalam pandangan Vygotsky interaksi sosial secara jelas mempengaruhi perkembangan kognitif. Keterampilan kognitif dan pola berpikir tidak hanya ditentukan oleh faktor bawaan tetapi sebagai hasil dari aktivitas yang dipraktikkan dalam lingkungan suatu kebudayaan tempat anak dibesarkan. Konsekuensinya, lingkungan anak dan dan latar belakang pribadi anak merupakan faktor penentu yang sangat penting terhadap cara individu berpikir (Mahn dalam Kozulin dkk., ed., 2003: 119-132; Portes dan Vadeboncoeur, dalam Kozulin dkk., ed., 2003: 375377). Paparan ini perlu bagi guru untuk memahami latar belakang siswanya.

Sehubungan dengan perkembangan bahasa dan kognisi, Vygotsky (Santrock, 2008: 40) menjelaskan bahwa kemampuan kognitif dimediasi melalui kata, bahasa, dan bentuk diskursus yang berfungsi sebagai alat psikologis untuk membantu mentransformasikan aktivitas mental. Vygotsky berpendapat bahwa pada masa 
anak usia dini, bahasa mulai digunakan sebagai alat yang membantu anak untuk merancang aktivitas dan memecahkan masalah.

Pada aplikasi pembelajaran menari kreatif, untuk mengembangkan ide anak, guru perlu memediasi anak dengan melakukan tanya jawab yang memberikan stimulasi pada pengembangan ide anak melalui metaphorming (Semiawan, 2010), maupun pembicaraan antar anak untuk terjadi curah pikiran tentang ide-ide yang muncul sehingga dimungkinkan terjadinya diskusi untuk pengembangan ide kreatif.

Penelitian ini menggunakan pendekatan penelitian tindakan (action research) yang dikembangkan oleh Kemmis dan Mc Taggart. Langkah-langkah penelitian model Kemmis dan Mc Taggart adalah sebagai berikut : (1) perencanaan (planning); (2) aksi atau tindakan (acting); (3) observasi (observing); (4) refleksi (reflecting); dan (5) perancanaan ulang (re-planning). Perencanaan ulang (re-planning) merupakan langkah yang dilaksanakan untuk merevisi berbagai kelemahan dalam pelaksanaan suatu siklus setelah dilakukan revisi dilaksanakan kembali pada siklus berikutnya. Penelitian ini melibatkan kolaborator yaitu guru tari dan guru kelas di TK kelas B Santa Ursula.

Data penelitian diambil melalui beberapa teknik antara lain; (a) pre-test dan post-test, digunakan untuk memperoleh data hasil belajar menari baik untuk awal maupun akhir pembelajaran; (b) observasi, dengan menggunakan lembar pengamatan, digunakan untuk memperoleh data tentang efektivitas dan peningkatan strategi pembelajaran yang digunakan oleh guru; (c) catatan lapangan, digunakan untuk memperoleh data tentang langkah-langkah pembelajaran yang digunakan oleh guru; (d) dokumentasi video dan foto, untuk memperoleh rekaman data proses pembelajaran sebagai data penunjang penelitian.

Data pre-test dan post-test hasil belajar menari dihitung dengan menggunakan data statistik. Untuk mengetahui peningkatan hasil belajar menari siswa pada saat pre-test dan post-test digunakan uji-t. Analisis data dengan uji-t bertujuan untuk memperoleh data tentang adakah peningkatan sebelum dan sesudah mendapatkan tindakan pembelajaran. Hasil belajar menari kreatif pada penelitian ini merujuk pada kelancaran, keluwesan, elaborasi, orisinalitas yang diungkapkan siswa melalui gerak dan rangkaian gerak tarinya.

Data efektivitas strategi pembelajaran yang dilakukan oleh guru diperoleh dengan melakukan analisis terhadap hasil observasi pada proses pembelajaran tari kreatif. Data observasi pembelajaran menjadi penjelasan data statistik. Data hasil analisis catatan lapangan digunakan untuk melengkapi data observasi. Pada data catatan lapangan termuat langkah-langkah pembelajaran yang dilakukan oleh guru.

Untuk memperoleh data penelitian digunakan tes praktik menari. Dari hasil tes praktik menari diperoleh data pada tes awal, nilai tertinggi adalah 75 dan nilai terendah 56. Rata-rata nilai 63,16. Pada tes akhir diperoleh data, nilai tertinggi adalah 76 dan nilai terendah 60. Rata-rata nilai 69,33 .

Berdasarkan hasil penghitungan data diperoleh data t-hitung sebesar 6,735> dari t-tabel 2,11 pada df17 taraf signifikasi 0,05 bahkan lebih besar dari $\mathrm{t}$ tabel 2,90 pada taraf signifikasi 0,01. Dengan demiki- 
an ada peningkatan hasil menari kreatif siswa. Berdasarkan data yang diperoleh secara kuantitatif dapat pula disimpulkan bahwa strategi pembelajaran Piaget dan Vygotsky efektif untuk digunakan pada pembelajaran tari kreatif di kelas B TK Santa Ursula. Data observasi kelas mendukung kesimpulan tersebut.

Penelitian kaji tindak bertujuan untuk memperbaiki pembelajaran. Penerapan strategi pembelajaran tari kreatif yang merujuk pada teori Piaget dan Vygotsky di kelas B TK Santa Ursula Jakarta Pusat, merupakan upaya memperbaiki strategi pembelajaran bidang pengembangan seni terutama seni tari. Penerapan strategi pembelajaran tari kreatif bukan tidak menemukan kendala pada awal pelaksanaannya. Kendala itu antara lain; (1) Karakteristik siswa dan kemampuan gerak siswa yang tidak homogen sehingga cukup memerlukan waktu untuk melakukan adaptasi pada materi pembelajaran yang baru; (2) Kemampuan siswa dalam mengambangkan ide belum optimal. Hal ini disebabkan strategi pembelajaran tari yang menekankan kepada penciptaan belum terbiasa dilakukan, karena selama ini siswa hanya melakukan gerak spontan dengan stimulus musik; (3) Kemampuan guru pada strategi pembelajaran kreatif belum memadai, sehingga pada awalnya strategi pembelajaran belum berkembang dengan optimal dan berpengaruh pada hasil belajar siswa. Kendala-kendala tersebut kemudian dapat diperbaiki pada proses pembelajaran. Hal ini berarti kreativitas guru dalam mengajar akan menjadi ujung tombak dalam pembelajaran tari kreatif.

Teori belajar Piaget menjelaskan bahwa pengetahuan anak diperoleh melalui konstruksi pengalaman belajar anak secara personal. Sementara Vygotsky menya- takan bahwa perolehan pengetahuan anak bukan hanya diperoleh dari pengalaman personal, tetapi terkait dengan interaksi anak dengan lingkungannya, sehingga peranan guru dan teman yang lebih mampu (More Knowledgeable Others) menjadi penting untuk membantu anak yang belum mampu dalam penguasaan tugas tertentu.

Aplikasi teori belajar Piaget di kelas penelitian ini pertama-tama bertujuan mendorong munculnya penemuan ekspresi gerak pribadi dari masing-masing siswa. Selanjutnya pada tahapan merangkaikan gerak tari yang memerlukan pengembangan ide peranan More Knowledgeable Others (MKO) yaitu peran orang lain yang lebih mampu menjadi berperanan dalam memberikan bantuan (asisted performance) pada siswa. Untuk mengembangkan ide atau pemikiran kreatif siswa, guru mengajukan pertanyaan-pertanyaan kepada siswa dengan tehnik metaphorming. Selain itu guru melakukan pengelompokan belajar, siswa yang belum mampu digabung dengan siswa yang lebih mampu. Dalam observasi penelitian tersebut strategi belajar nampak efektivitasnya.

Pembelajaran tari kreatif tidak hanya mencakup pengembangan keterampilan motorik semata, tetapi juga mengembangkan kemampuan musikal, kemampuan intra dan interpersonal siswa. Di dalam kerja kelompok siswa TK kelas B Santa Ursula, mereka mampu bekerja sama untuk melakukan ekspresi gerak, mencari gerak dan akhirnya menjadi susunan gerak tari yang bermakna dan terstruktur dengan musik pengiring, melalui proses hasil sintesa pemikiran dan penemuan gerak tari sebelumnya, dengan bantuan guru sebagai fasilitator. Hal Ini berarti kemampuan berbahasa nonverbal (bahasa ge- 
rak) anak dilatih sejak usia dini. Di dalam tari tidak hanya bahasa nonverbal, tetapi juga bahasa verbal dilatihkan antara lain melalui tanya jawab dan penjelasan anak tentang ide gerak tari yang ditemukan dan dikembangkannya. Dengan demikian pembelajaran tari dalam praktiknya tidak hanya mengajarkan siswa menguasai tarian semata, tetapi juga harus mampu memunculkan potensi lintas bidang aspek kecerdasan jamak.

Pembelajaran tari kreatif tidak hanya secara efektif mampu meningkatkan kemampuan menari siswa TK kelas B Santa Ursula, tetapi juga telah memberikan pengalaman pada guru dalam refleksi diri dan memecahkan masalah pembelajaran. Guru mampu mengidentifikasikan permasalahan pembelajaran yang terjadi pada masing-masing individu siswa. Guru kelas dan guru tari mampu berkolaborasi memperbaiki pembelajaran dan senantiasa melakukan refleksi setelah pembelajaran usai. Penelitian tindakan ini telah memberi kontribusi pada visi guru dalam mengelola pembelajaran dengan baik melalui pendekatan reflektif dan kolaboratif.

Pembelajaran tari kreatif dengan pendekatan Piaget dan Vygotsky yang lebih memusatkan pada belajar siswa secara konstruktif dan kreatif ternyata membawa dampak positif pada motivasi dan disiplin siswa dalam belajar. Motivasi dan kedisiplinan ini terjadi disebabkan siswa merupakan subjek pembelajaran dalam kelompoknya masing-masing. Selain itu tanggungjawab siswa terhadap kelompoknya nampak pada kebersamaan siswa untuk saling membelajarkan. Di mana intinya siswa yang telah mampu berbagi pengetahuan dengan siswa yang belum mampu. Dengan demikian, perbaikan pembelajaran tari melalui strategi pembelajaran Piaget dan Vygotsky terbukti efektif dilakukan pada TK kelas B Santa Ursula Jakarta Pusat.

\section{PENUTUP}

Dari hasil pengamatan penelitian tindakan ini dapat disimpulkan sebagai berikut:

1. Strategi pembelajaran Piaget dan Vygotsky pada pembelajaran tari kreatif efektif digunakan untuk meningkatkan kemampuan menari siswa kelas B TK Santa Ursula Jakarta Pusat

2. Bentuk tari yang merujuk kepada tema pembelajaran, merupakan rangkaian gerak tari yang terstruktur dan bermakna, hasil proses pemikiran atau ide siswa yang diungkapkan melalui gerak yang ditemukan dari eksplorasi dan improvisasi yang selanjutnya disusun atau dirangkaikan oleh siswa baik secara individual maupun berkelompok, dengan guru sebagai fasilitator. Strategi pembelajaran ini dapat diterapkan di TK B.

3. Tema dapat dijadikan sebagai stimulasi pada pembelajaran tari kreatif untuk memunculkan dan mengembangkan imajinasi kreatif siswa.

4. Siswa kelas B TK Santa Ursula Jakarta Pusat memiliki kemampuan menari kreatif lebih baik melalui strategi pembelajaran Piaget dan Vygotsky. 


\section{DAFTAR PUSTAKA}

\section{Sumber Tulisan}

Autard, Jaqueline M, Smith.

1994 The Art of Dance in Education. London: A \& C Black.

Clark, B.

1988 Growing Up Gifted. Third Edition. Columbus Ohio: C.E. Merril Publishing Company, A Bell and Howell Company.

Conny Semiawan.

2009 Penerapan Pembelajaran pada Anak.

Yufiarti dan Theodorus Immanuel Setiawan (edt). Jakarta: PT. Indeks.

2010 Pelatihan guru TK Labschool tentang "Metaphorming". Jakarta: Labschool Rawamangun.

Gardner, Howard.

1993 Multiple Intelligences: The Theory in Practice, New York: Basic Book.

Hasselbach, Barbara.

1978 Dance Education: Basic Principles and Models for Nursery and Primary School. London: Schott \& Co. Ltd.

Kaufman, James C., Robert J. Sternberg.

2010 The Cambridge Handbook of Creativity. Mengutip. Mark A Runco. New York: Cambridge University Press.

Kozulin, Alex., et al.

2003 Vygotsky's Educational Theory in
Cultural Context. Cambridge-England:The MIT Press.

Laban, Rudolf.

1976 Modern Educational Dance. ed. 3. Revised by Ulmann. London:Macdonald and Evans.

Mahn, Holbrook.

2003 "Periods in Child Development: Vygotsky's Perspective", dalam Vygotsky's Educational Theory in Cultural Context diedit oleh Kozulin et al. New York: Cambridge University Press.

Muller, Ulrich.

2009 The Cambridge Companion to Piaget. New York: Cambridge University Press.

Muray, Ruth Lovell.

1975 Dance in Elementary Education. New York: Harper \& Row Publishers.

Paul Suparno.

1997 Filsafat Konstruktivisme dalam Pendidikan. Yogyakarta: Kanisius.

2001 Teori Perkembangan Kognitif Jean Piaget. Yogyakarta: Kanisius.

Portes, R Pedro., Vadeboncoeur, A Jennifer. 2003 "Mediation in Cognitive Socialization: The Influence oof Socioeconomic Status"dalam Vygotsky's Educational Theory in Cultural Context diedit oleh Kozulin et al. New York: Cambridge University Press. 
Runco, Mark A.

1996 Creativity from Childhood Through Adulthood: The Developmental Issues. San Francisco: Jossey Bass, Publishers.

Santrock, John W.

2008 Educational Psychology Third Edition, Dallas:Mc Graw Hill.

Utami Munandar.

1977 Creativity and Education. Jakarta: Proyek Pengadaan Buku Direktorat Pembinaan Penelitian dan Pengabdian Masyarakat. Dirjen Depdikbud.

Vernon, E.P.

1982 Creativity. Baltimore: The Chaucer Press, Ltd, Penguin Books.

Wina Sanjaya.

2007 Strategi Pembelajaran, Berorientasi Standar Proses Pendidikan. Jakarta: Kencana Prenada Media Grup.

\section{Sumber Virtual}

Chad, Galloway.

"Vygotsky Constructionism". Http:// www.coe.uga/epltt/vygotskyconstru ctionism.htm. Minggu 2 Oktober 2011, pukul 11.35 WIB.

Cristin, Guerra.

Lev Semyonovich Vygotsky. Http://www. muskingum.edu/ psych/psycweb/history/vygotsky. htm. Minggu 2 Oktober 2011, pukul 14.21 WIB 